\title{
Measurements of optical properties of atmospheric aerosols in Northern Finland
}

\author{
V. Aaltonen ${ }^{1}$, H. Lihavainen ${ }^{1}$, V.-M. Kerminen ${ }^{1}$, M. Komppula ${ }^{1}$, J. Hatakka ${ }^{1}$, K. Eneroth $^{2}$, M. Kulmala ${ }^{3}$, and \\ Y. Viisanen ${ }^{1}$ \\ ${ }^{1}$ Climate and Global Change Research, Finnish Meteorological Institute, P.O. Box 503, 00101 Helsinki, Finland \\ ${ }^{2}$ Department of Applied Environmental Science, Stockholm University, 10691 Stockholm, Sweden \\ ${ }^{3}$ Department of Physical Sciences, Division of Atmospheric Sciences, P.O. Box 64, 00014 University of Helsinki, Finland
}

Received: 14 September 2005 - Published in Atmos. Chem. Phys. Discuss.: 15 November 2005

Revised: 7 February 2006 - Accepted: 7 February 2006 - Published: 11 April 2006

\begin{abstract}
Three years of continuous measurements of aerosol optical properties and simultaneous aerosol number size distribution measurements at Pallas GAW station, a remote subarctic site in the northern border of the boreal forest zone, have been analysed. The scattering coefficient at $550 \mathrm{~nm}$ varied from 0.2 to $94.4 \mathrm{Mm}^{-1}$ with an average of $7.1 \pm 8.6 \mathrm{Mm}^{-1}$. Both the scattering and backscattering coefficients had a clear seasonal cycle with an autumn minimum and a 4-5 times higher summer maximum. The scattering was dominated by submicron aerosols and especially so during late summer and autumn. The Ångström exponent had a clear seasonal pattern with maximum values in late summer and minimum values during wintertime. The highest hemispheric backscattering fraction values were observed in autumn. To analyse the influence of air mass origin on the aerosol optical properties a trajectory climatology was applied to the Pallas aerosol data. The most polluted trajectory patterns represented air masses from the Kola Peninsula, Scandinavia and Russia as well as long-range transport from Britain and Eastern Europe. These air masses had the largest average scattering and backscattering coefficients for all seasons. Higher than average values of the Ångström exponent were also observed in connection with transport from these areas.
\end{abstract}

\section{Introduction}

There is a growing evidence that the Earth's radiation budget, and thus climate, is affected through radiative forcing caused by changes in the concentration and composition of aerosol particles (Lohmann and Feichter, 2005; Ramanathan et al., 2001; Charlson et al., 1999; Hansen et al., 1997). However,

Correspondence to: V. Aaltonen

(veijo.aaltonen@fmi.fi) owing to their high spatial and temporal variability (seasonal dust storms or biomass burning), the globally and annually averaged climatic forcing by aerosols is associated with large uncertainties (IPCC, 2001).

Aerosol optical properties and their relation to other aerosol properties are key factors in investigating the direct radiative effects by atmospheric aerosols. The most important particles in this respect are submicron accumulation mode particles (Charlson et al., 1999). However, supermicron sea salt and dust may also have an important role in scattering in certain conditions (O'Dowd and Smith, 1993). Measurements concerning aerosol optical properties have been made in the marine boundary layer (e.g. Hegg et al., 1996), at a few coastal sites (e.g. O'Dowd and Smith, 1993; Sheridan and Ogren, 1999; Delene and Ogren, 2002; Anderson et al., 1999), in the free troposphere (e.g. Sheridan and Ogren, 1999), in Arctic regions (e.g. Virkkula et al., 1998; Treffeisen et al., 2004; Beine et al., 1996), and in areas with a high sulfate burden (e.g. Koloutsou-Vakakis et al., 2001; Delene and Ogren, 2002). High Arctic aerosol loadings, i.e. Arctic haze, have also been investigated (e.g. Treffeisen et al., 2004; Heintzenberg et al., 2003; Beine et al., 1996). In addition to field measurements, aerosol optical properties have been studied with airborne in-situ measurements as well as from satellites (e.g. Bodhaine et al., 1991; Kaufman et al., 2002).

Although the optical properties of particles with different size have been studied widely, there is still a need for measurements from remote or moderately polluted areas. In this study we present results from simultaneous aerosol scattering and size distribution measurements conducted at a remote continental subarctic site. The data covers three years of continuous measurements. Our purpose is to illustrate 1) how the aerosol optical properties (scattering and backscattering coefficients, Ångström exponent, hemispheric backscattering fraction) vary seasonally and with air mass origin, and

Published by Copernicus GmbH on behalf of the European Geosciences Union. 


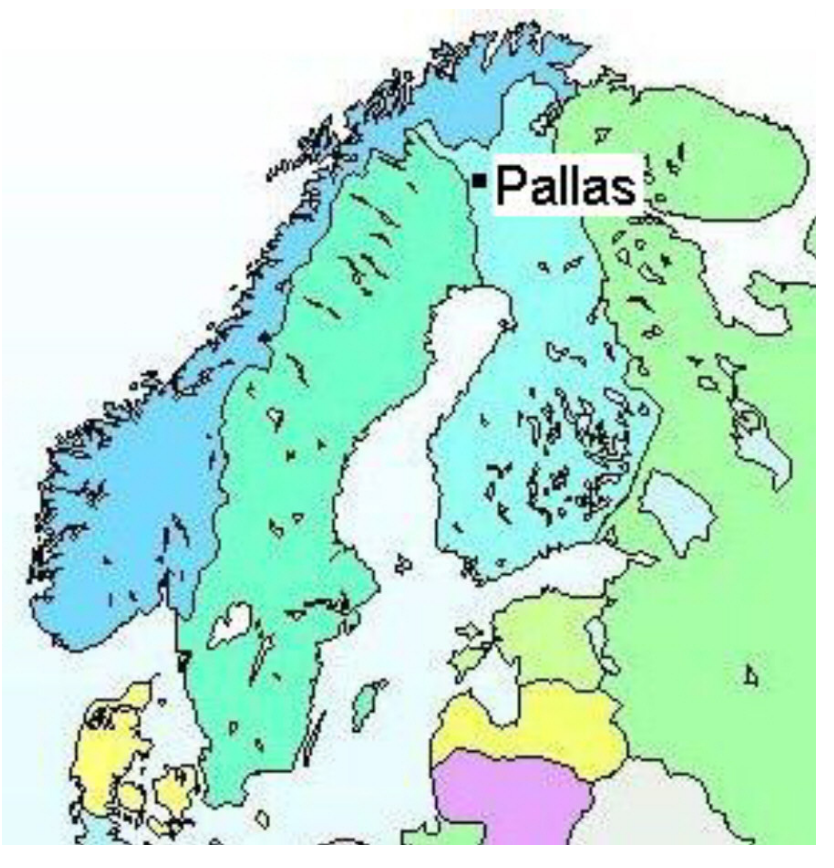

Fig. 1. Location of the Pallas GAW station in Northern Finland.

2) how the optical properties are related to the properties of measured aerosol number size distributions.

\section{Instrumentation and methods}

\subsection{Site description}

The Finnish Meteorological Institute (FMI) has participated in the Global Atmosphere Watch (GAW) programme since 1994 and maintains the Pallas-Sodankylä GAW station. The main measuring station (Fig. $1,67^{\circ} 58^{\prime} \mathrm{N}, 24^{\circ} 07^{\prime} \mathrm{E}$ ) is located on a top of fjeld (an Arctic hill) Sammaltunturi, at the height of $560 \mathrm{~m}$ above sea level, and ca. $300 \mathrm{~m}$ above the surrounding area. The measuring site is very suitable for tropospheric measurements due to the absence of large local and regional pollution sources. The distance to the nearest town, Muonio, with some 2500 inhabitants, is $19 \mathrm{~km}$ to the west. The second nearest town, Kittilä (6000 inhabitants) is $46 \mathrm{~km}$ to the south-east. The closest major pollution sources are the smelters Nikel and Montshegorsk in Russia, located about $350 \mathrm{~km}$ away from Pallas, Nikel to the northeast and Montshegorsk to the east. A detailed description on the site is given by Hatakka et al. (2003).

\subsection{Instrumentation}

The scattering $\left(\sigma_{s p}\right)$ and backscattering coefficients $\left(\sigma_{b s p}\right)$ were measured with an integrating nephelometer (model 3563, TSI, Inc., St. Paul, Minnesota). The measurements at Pallas have been going on continuously since February 2000.
The instrument measures scattering $\left(\sigma_{s p}\right)$ and backscattering coefficients $\left(\sigma_{b s p}\right)$ in three wavelengths, 450,550, and $700 \mathrm{~nm}$. The instrument illuminates the sample volume from the side and measures the light scattered by aerosol particles and gas molecules in the direction of the photomultiplier tube integrating the scattering over angle of $7-170^{\circ}$. The instrument is described in detail by Anderson et al. (1996) and Bodhaine et al. (1991). Calibration of the nephelometer is carried out at least twice per year by using $\mathrm{CO}_{2}$ (purity 4.0) as high span gas and filtered air as low span gas. The averaging time is set to $5 \mathrm{~min}$. The zero signal is measured once an hour.

The inlet of the main sampling line is about $3 \mathrm{~m}$ above the roof of the measurement station building, about $7 \mathrm{~m}$ above the ground. Calculated (Baron and Willeke, 2001) cut off diameter of the inlet nozzle and sample transport lines was about $5 \mu \mathrm{m}$. More detailed description of the inlet system is found in Komppula et al. (2005).

The sample air is heated to station indoor temperature (about $20^{\circ} \mathrm{C}$ ) prior to entering the nephelometer. The heater inside the nephelometer was not activated until December 2003. The heater decreases condensation inside the measurement chamber. Before turning the heater on, the mean relative humidity $(R H)$ was $18 \pm 10 \%$, the maximum hourly mean $R H$ being $60 \%$. After turning the heater on, the mean $R H$ was $9 \pm 3 \%$ and the maximum hourly mean $R H$ was $23 \%$.

The particle number size distribution in the range 7$500 \mathrm{~nm}$ was measured with a Differential Mobility Particle Sizer (DMPS). Continuous DMPS measurements were started on 13 April 2000. The instrument and measuring arrangements have been described in detail by Komppula et al. (2003).

The total aerosol number concentration was measured with a Condensation Particle Counter (CPC, TSI model 3010). These measurements have been going on since 28 June 1996. The CPC measures particles larger than about $10 \mathrm{~nm}$. Concentration of particles larger than $0.5 \mu \mathrm{m}$ was measured with a Laser Particle Counter (LPC, TSI model 7550) between October 1998 and April 2004. The instrument measures number concentration of aerosol particles in two size channels, $D_{p}>0.5 \mu \mathrm{m}$ and $D_{p}>5.0 \mu \mathrm{m}$. The upper channel could not be used in the analysis because of the cut off in the transport line.

Other measurements in Pallas include trace gas measurements and meteorological parameters. In this analysis we used $\mathrm{SO}_{2}$ concentration as well as visibility measured with a Vaisala FD12P weather sensor. The detection limit of the $\mathrm{SO}_{2}$ measurements, carried out with Thermo Electron $43 \mathrm{~S}$, is $0.1 \mu \mathrm{g} \mathrm{m}^{-3}$. The meteorological measurements are made with an automatic weather station (Hatakka et al., 2003).

\subsection{Data processing}

Measurement data were analysed for the period from 9 November 2001 to 9 November 2004. The data associated 
with abnormal peaks, calibrations or visits at the station were rejected, as were also the cases when the zero mode was not activated, values when the $R H$ inside the nephelometer exceeded $40 \%$, or the station was inside clouds.

Nonidealities due to nonlambertian and truncation errors were corrected using the method described by Anderson and Ogren (1998). Nonlambertian errors are most important for sub-micron particles whereas truncation errors are most important for $>1 \mu \mathrm{m}$ particles (Anderson and Ogren, 1998). Nonlambertian error is the slightly noncosine-weighted intensity distribution of illumination light provided by the opal glass diffusor of the nephelometer. Truncation error is the geometrical blockage of near-forward-scattered light for angles below about $7^{\circ}$.

For 5-min averages applied here, the detection limits for total scattering coefficients are $0.44,0.17$, and $0.26 \mathrm{Mm}^{-1}$ for 450,550 , and $700 \mathrm{~nm}$, respectively (Anderson et al., 1996). For backscattering, the detection limits are $0.29,0.11$, and $0.21 \mathrm{Mm}^{-1}$ for 450,550 , and $700 \mathrm{~nm}$, respectively. Values below these detection limits were excluded. Hourly averages were calculated from valid results.

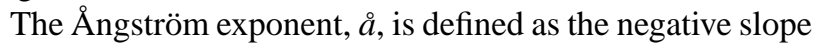
of the logarithm of scattering coefficient as a function of wavelength and is given by $\sigma_{s p}=K \lambda^{-\stackrel{a}{a}}$, where $K$ is a constant. In practice, $\stackrel{a}{a}$ is calculated from the equation

$\stackrel{a}{a}=-\frac{\log \sigma_{s p(700 \mathrm{~nm})}-\log \sigma_{s p(550 \mathrm{~nm})} .}{\log 700-\log 550}$.

A large Ångström exponent implies an aerosol size distribution with scattering dominated by submicron particles, while a distribution dominated by coarse particles has typically smaller $\stackrel{\circ}{a}$. The hemispheric backscattering fraction, $b$, was obtained from $b=\sigma_{b s p} / \sigma_{s p}$.

\subsection{Cluster analysis}

To analyse the influence of air-mass origin on the optical aerosol measurements at Pallas, three-dimensional 5-day back-trajectories arriving at $925 \mathrm{hPa}$ were calculated, using the kinematic model FLEXTRA (Stohl and Wotawa, 1995; Stohl and Koffi, 1998; Stohl et al., 1999). The model utilizes meteorological data from the European Centre for Medium Range Weather Forecasts (ECMWF). The calculations were performed twice daily (00:00 and 12:00 UTC) during the period 1997-2003, resulting in a data set of 5112 trajectories.

The trajectories were classified into different flow patterns with the use of cluster analysis. Cluster analysis denotes a variety of multivariate techniques used to group similar objects together, whereby differences between individual elements within a cluster are minimized but differences between clusters are maximized (Romesburg, 1984). In the present study the Ward's minimum variance technique was used, provided in a Matlab standard statistical package. Seven transport patterns, representing the atmospheric flow to Pallas during the 7-year period 1997-2003, were identified. The clustering

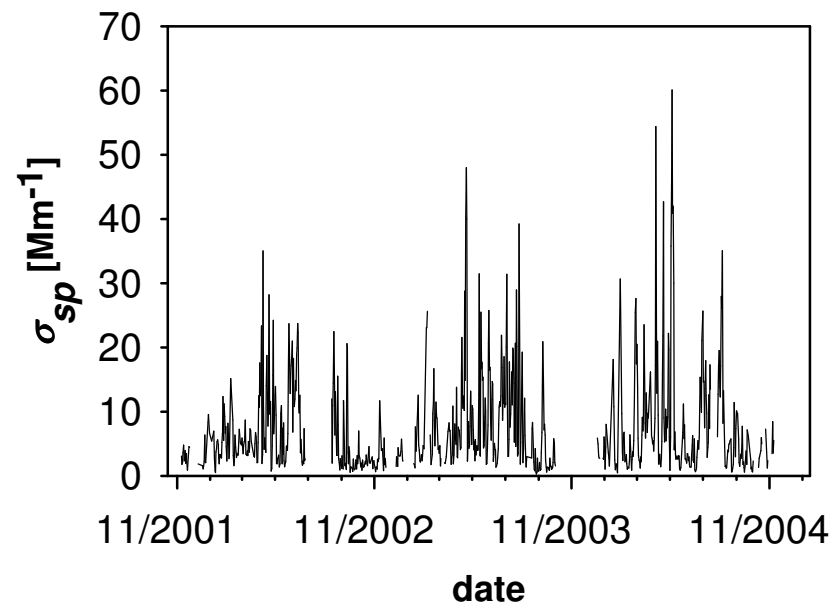

Fig. 2. Time-series of $\sigma_{s p}$ at $550 \mathrm{~nm}$.

procedure and the resulting trajectory climatology are described in detail by Eneroth et al. (2005).

\section{Results and discussion}

\subsection{General features}

Figure 2 shows daily mean scattering coefficients $\sigma_{s p}$ at $550 \mathrm{~nm}$ covering the whole measurement period. The value of $\sigma_{s p}$ varies widely - more than two orders of magnitude. This variation is embedded in the consistent seasonal cycle discussed below. Gaps in the data are mainly due to burned lamp or maintenance.

Statistical properties of the hourly mean values of the measured and calculated parameters are presented in Table 1 . Based on three years of hourly averaged data, $\sigma_{s p}$ at $550 \mathrm{~nm}$ varied in the range $0.2-94.4 \mathrm{Mm}^{-1}$ with an average of $7.1 \mathrm{Mm}^{-1}$ and a standard deviation (STD) of $8.6 \mathrm{Mm}^{-1}$. These values are comparable to those measured at other Arctic sites, including three years of measurements in Barrow, Alaska (Delene and Ogren, 2002) and measurements made in spring 1994 in Ny-Ålesund, Svalbard (Beine et al., 1996). Much larger, typically 1-2 orders of magnitude, scattering coefficients have been measured in sites affected by urban or continental pollution (e.g. Cabada et al., 2004; Vrekoussis et al., 2005).

The seasonal variation of various optical parameters can best be seen from the monthly-average data, which is shown in Fig. 3. Both the scattering and backscattering coefficients display a clear seasonal cycle with an autumn minimum and a 4-5 times higher summer maximum. These two parameters started to rise early in spring, reaching their highest values in summer. After July the values decreased very rapidly and stayed relative constant during the autumn. The autumn scattering minimum may be related to the fact that both cloudiness and precipitation have their maximum in autumn, 
Table 1. Statistics of aerosol optical parameters. The averages are expressed as arithmetic means (AM), and variations as standard deviations (STD). Scattering and backscattering coefficients are given in unit $\mathrm{Mm}^{-1}$, while DMPS and LPC number concentrations are given in particles $\mathrm{cm}^{-3} . \mathrm{SO}_{2}$ concentrations are given in $\mu \mathrm{g} / \mathrm{m}^{3}$.

\begin{tabular}{lccccccc}
\hline & & & & \multicolumn{5}{c}{ Percentiles } \\
\cline { 5 - 8 } Parameter & $\mathrm{N}$ & $\mathrm{AM}$ & $\mathrm{STD}$ & 10 & 50 & 90 & 99 \\
\hline$\sigma_{s p(450 \mathrm{~nm})}$ & 13357 & 10.2 & 12.6 & 1.5 & 5.5 & 24.7 & 65.3 \\
$\sigma_{s p(550 \mathrm{~nm})}$ & 13381 & 7.1 & 8.6 & 1.0 & 3.9 & 16.8 & 44.4 \\
$\sigma_{s p(700 \mathrm{~nm})}$ & 13325 & 4.6 & 5.5 & 0.6 & 2.7 & 10.7 & 26.9 \\
$\sigma_{b s p(450 \mathrm{~nm})}$ & 12833 & 1.2 & 1.2 & 0.4 & 0.7 & 2.6 & 6.4 \\
$\sigma_{b s p(550 \mathrm{~nm})}$ & 13263 & 0.9 & 1.0 & 0.2 & 0.5 & 2.1 & 5.1 \\
$\sigma_{b s p(700 \mathrm{~nm})}$ & 12428 & 0.9 & 0.9 & 0.3 & 0.6 & 1.9 & 4.5 \\
$a_{550 / 450 \mathrm{~nm}}$ & 13349 & 1.7 & 0.6 & 0.9 & 1.8 & 2.4 & 3.2 \\
$a_{700 / 450 \mathrm{~nm}}$ & 13280 & 1.8 & 0.7 & 0.8 & 1.8 & 2.7 & 3.9 \\
$\check{a}_{700 / 550 \mathrm{~nm}}$ & 13311 & 1.8 & 1.0 & 0.6 & 1.8 & 3.1 & 4.7 \\
$b_{450 \mathrm{~nm}}$ & 12823 & 0.1 & 0.1 & 0.1 & 0.1 & 0.2 & 0.5 \\
$b_{550 \mathrm{~nm}}$ & 13261 & 0.1 & 0.1 & 0.1 & 0.1 & 0.2 & 0.4 \\
$b_{700 \mathrm{~nm}}$ & 12419 & 0.2 & 0.1 & 0.1 & 0.2 & 0.3 & 0.6 \\
$\mathrm{~N}_{\text {total }}$ & 11151 & 764 & 736 & 94 & 528 & 1783 & 3132 \\
$\mathrm{~N}_{\text {nucl }}$ & 11151 & 145 & 283 & 10 & 48 & 366 & 1410 \\
$\mathrm{~N}_{\text {aitken }}$ & 11151 & 375 & 464 & 31 & 206 & 979 & 2007 \\
$\mathrm{~N}_{\text {accum }}$ & 11151 & 243 & 310 & 29 & 118 & 644 & 1436 \\
$\mathrm{~N}_{100-200 \mathrm{~nm}}$ & 11224 & 173 & 238 & 17 & 74 & 482 & 1066 \\
$\mathrm{~N}_{200-300 \mathrm{~nm}}$ & 11224 & 56 & 74 & 5 & 30 & 138 & 366 \\
$\mathrm{~N}_{300-400 \mathrm{~nm}}$ & 11224 & 14 & 19 & 1 & 6 & 36 & 98 \\
$\mathrm{~N}_{400-500 \mathrm{~nm}}$ & 11204 & 4 & 5 & 0 & 2 & 9 & 26 \\
$\mathrm{~N}_{>100 \mathrm{~nm}}$ & 11189 & 247 & 320 & 29 & 119 & 650 & 1474 \\
$\mathrm{~N}_{>200 \mathrm{~nm}}$ & 11189 & 73 & 96 & 7 & 38 & 181 & 488 \\
$\mathrm{~N}_{>300 \mathrm{~nm}}$ & 11189 & 17 & 24 & 2 & 8 & 45 & 123 \\
$\mathrm{~N}_{>500 \mathrm{~nm}, \mathrm{LPC}}$ & 10505 & 2 & 2 & 0 & 1 & 4 & 9 \\
$\mathrm{SO}_{2}$ & 12901 & 0.5 & 1.3 & 0.0 & 0.2 & 1.0 & 4.9 \\
\hline & & & & & & & \\
\hline
\end{tabular}

and therefore the air is expected to be cleaner. The scattering coefficient usually reached its maximum in July and minimum in October. The backscattering coefficient behaved in the same way, though with lower absolute values. At Barrow, Alaska, $\sigma_{s p}$ was lowest in summer and highest (10-15 times higher than summer values) in winter (Delene and Ogren, 2002). High values at Barrow in winter are related to a winter maximum in submicron sulfate aerosol and sea-salt aerosol mass concentration, indicating periods of Arctic haze as well as high sea-salt mass concentrations.

The Ångström exponent also had a clear seasonal variation with a minimum in spring and a 2-4 times higher maximum in late summer. Based on the absolute values of $\stackrel{a}{a}$, we conclude that scattering is dominated by submicron aerosols in Pallas, and especially so during late summer and autumn. The hemispheric backscattering fraction $b$ at $550 \mathrm{~nm}$ varied by roughly a factor two between the months but does not show a consistent seasonal pattern.

\subsection{Relationships between the measured quantities}

The scattering and backscattering coefficients were found to be strongly correlated to each other. The ratio of these two quantities, the hemispheric backscattering fraction $b$, was also found to be dependent on the magnitude of $\sigma_{s p}$ (Fig. 4). For $\sigma_{s p}>1 \mathrm{Mm}^{-1}$, the value of $b$ decreased gradually with increasing $\sigma_{s p}$, being mostly below 0.2 when $\sigma_{s p}>10 \mathrm{Mm}^{-1}$. This kind of pattern is consistent with observations made by Delene and Ogren (2002) at four different sites in Northern America. Interestingly, $b$ started to increase very rapidly with decreasing $\sigma_{s p}$ in very clean air $\left(\sigma_{s p}<1 \mathrm{Mm}^{-1}\right)$. A closer look at the particle size distribution data revealed that these cases were characterized by very low accumulation mode particle number concentrations, as well as a particle size distribution strongly dominated by ultrafine particles. This observation agrees with the fact that as particles get smaller $(<100 \mathrm{~nm})$, their backscattering fraction increases substantially (e.g. Seinfeld and Pandis, 1998).

Figure 5 displays $\sigma_{s p}$ as a function of the particle number concentration in different modes, including the accumulation 

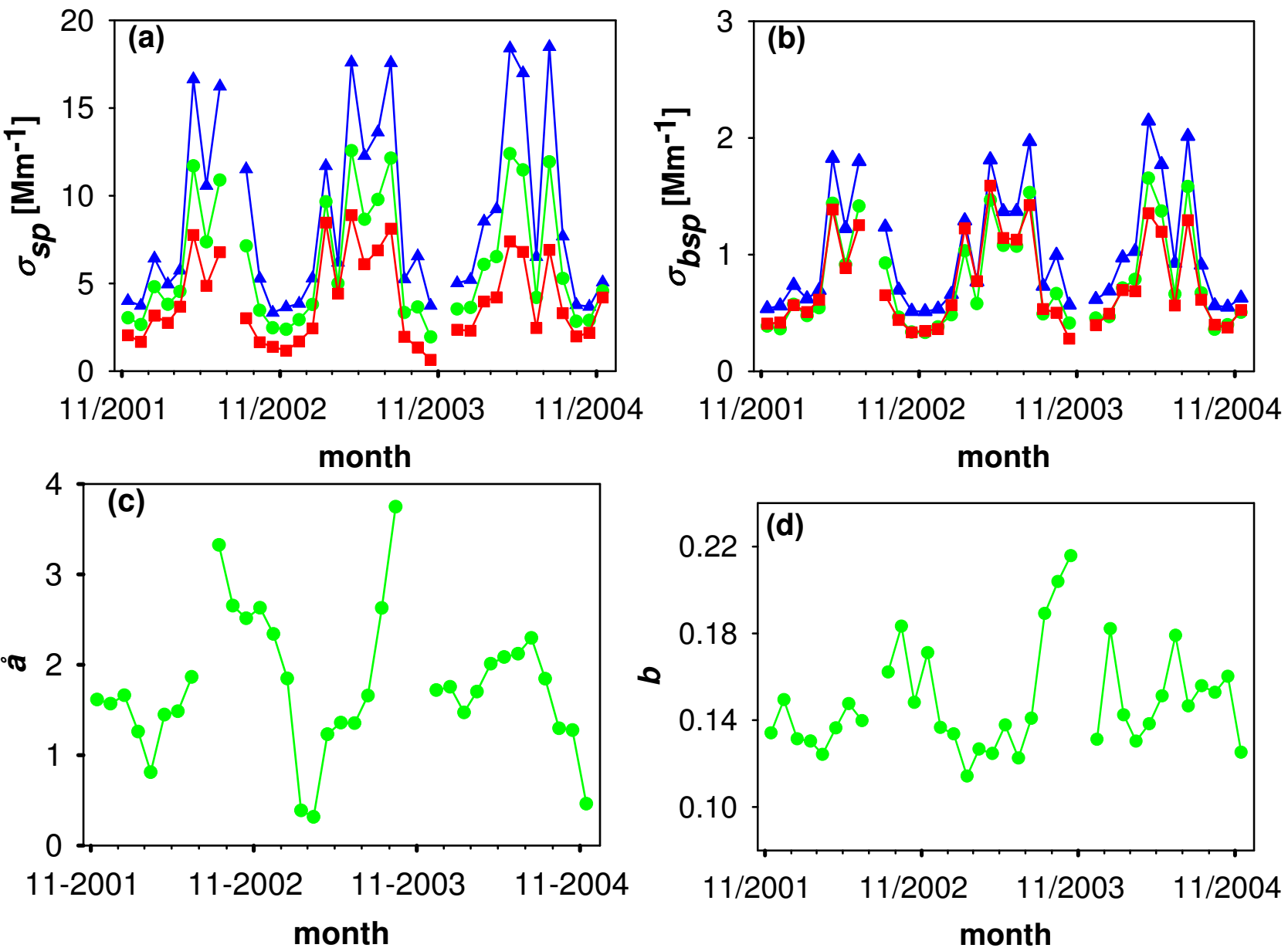

Fig. 3. Monthly average values of (a) $\sigma_{s p}$ at three wavelengths, (b) $\sigma_{b s p}$ at three wavelengths, (c) $\stackrel{a}{a}$ and (d) $b$ at $550 \mathrm{~nm}$. Blue triangles, green circles and red squares correspond to $\sigma_{s p}$ and $\sigma_{b s p}$ values at $450 \mathrm{~nm}, 550 \mathrm{~nm}$, and $700 \mathrm{~nm}$, respectively.

mode (particle diameter 95-500 nm), aitken mode (25$95 \mathrm{~nm})$ and nucleation mode $(7-25 \mathrm{~nm})$. Aerosol particles in the accumulation mode have the highest scattering efficiency at measured wavelengths. This can be seen as a clear correlation between $\sigma_{s p}$ and the number concentration of accumulation mode particles (Fig. 5a). The relation between $\sigma_{s p}$ and the number concentration of nucleation mode particles displays an envelope type pattern (Fig. 5b), with high values of $\sigma_{s p}$ being always associated with low nucleation mode particle number concentration and vice versa. This kind of behaviour can be explained in two ways: 1) no major primary sources (such as traffic emissions) for nucleation mode particles observed at Pallas exist, and 2) atmospheric new-particle formation at Pallas takes place only in clean air masses originating from the North Atlantic or the Arctic Ocean (Komppula et al., 2003). The connection between $\sigma_{s p}$ and aitken mode reminds that between $\sigma_{s p}$ and nucleation mode, even though the envelope type pattern is less clear (Fig. 5c). No clear connection between $\sigma_{s p}$ and total particle number concentration could be seen (Fig. 5d).

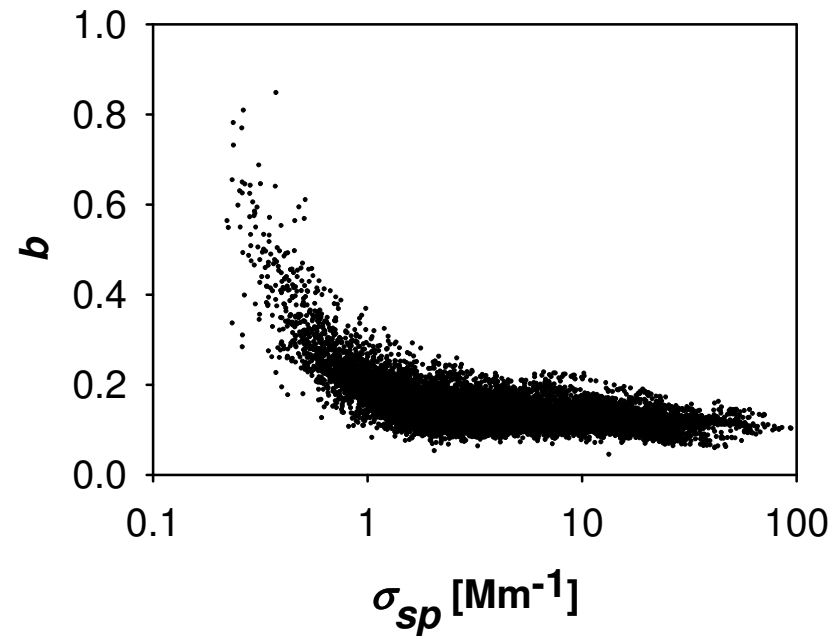

Fig. 4. Relation between $\sigma_{s p}$ and $b$ at $550 \mathrm{~nm}$. 

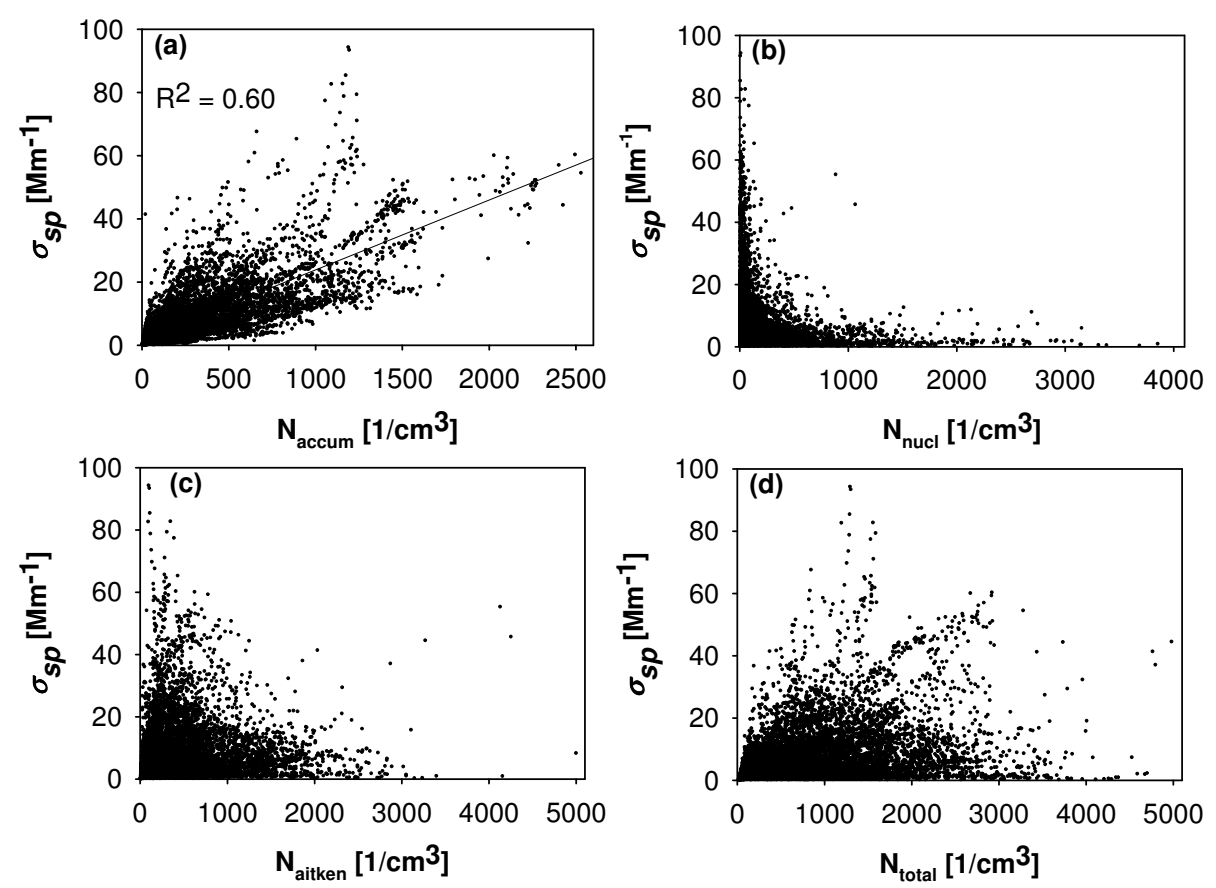

Fig. 5. Relation between $\sigma_{s p}$ at $550 \mathrm{~nm}$ and (a) accumulation mode, (b) nucleation mode, (c) aitken mode and (d) total particle number concentration.
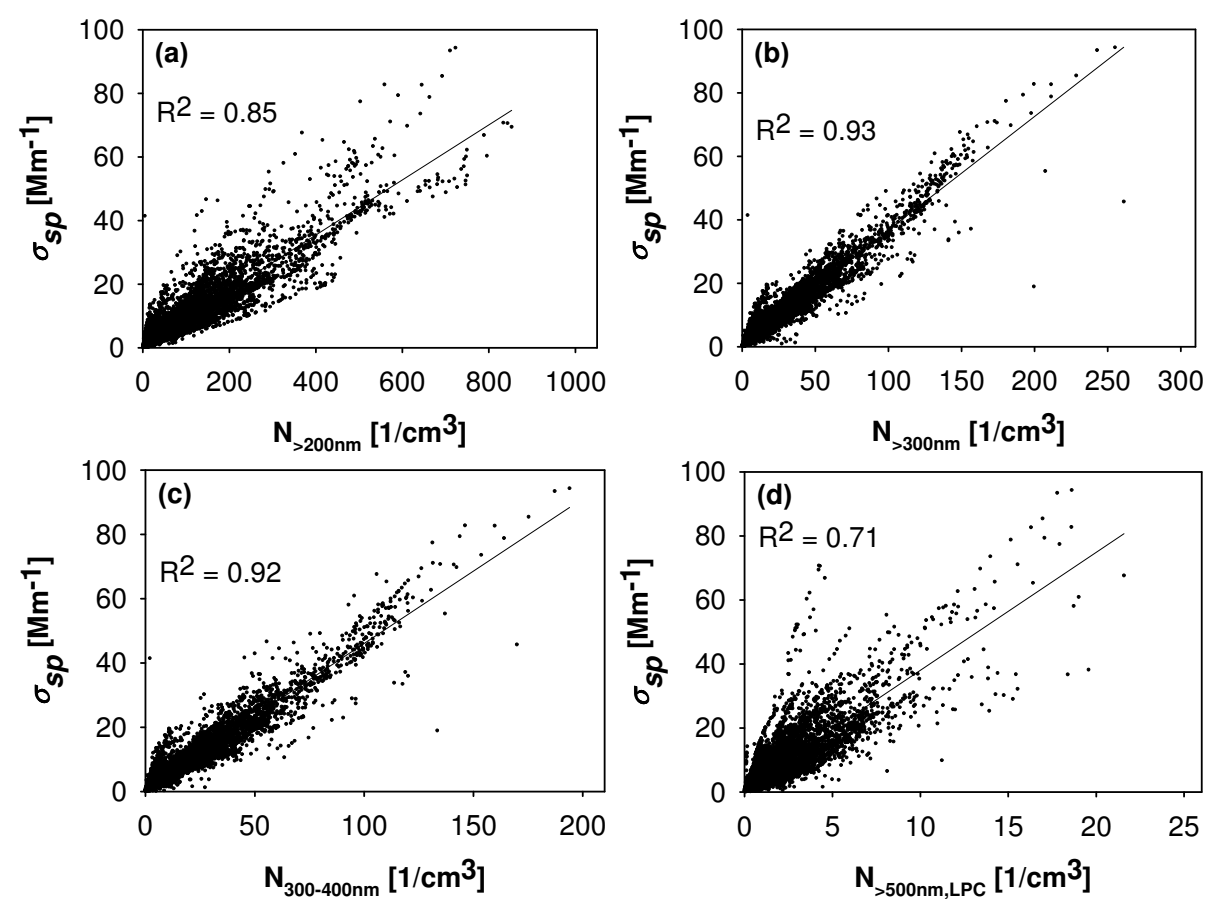

Fig. 6. Relation between $\sigma_{s p}$ at $550 \mathrm{~nm}$ and concentration of (a) $>200 \mathrm{~nm}$ particles, (b) $>300 \mathrm{~nm}$ particles, (c) $300-400 \mathrm{~nm}$ particles measured with DMPS and (d) $>500 \mathrm{~nm}$ particles measured with LPC.

The scattering coefficient $\sigma_{s p}$ correlated strongly with the particle number concentration measured by the LPC (Fig. 6d,
$\mathrm{R}^{2}=0.71$, which is consistent with the results by Virkkula et al. (1998) at another Finnish Arctic site. This correlation 


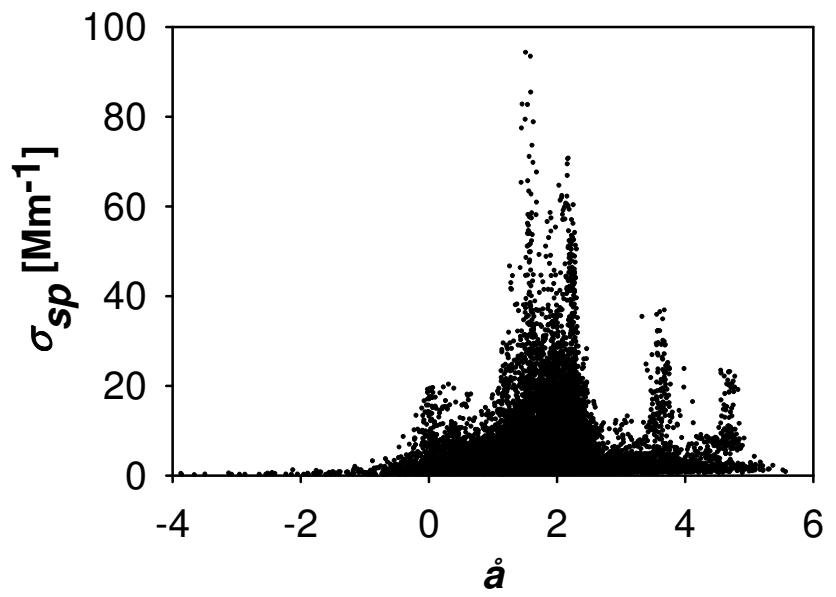

Fig. 7. Relation between $\sigma_{s p}$ at $550 \mathrm{~nm}$ and $\stackrel{\circ}{\text {. }}$

is higher than that of $\sigma_{s p}$ with the number concentration of accumulation mode particles $\left(\mathrm{R}^{2}=0.60\right)$, but lower than that of $\sigma_{s p}$ with $400-500 \mathrm{~nm}$ particles $\left(\mathrm{R}^{2}=0.87\right)$ or with 300 $400 \mathrm{~nm}$ particles (Fig. 6c, $\mathrm{R}^{2}=0.92$ ). By looking at particles larger than a certain threshold size, rather than by looking at specific size ranges, a complementary picture emerges. For example, the correlation between $\sigma_{s p}$ and $>200 \mathrm{~nm}$ particles was 0.85 (Fig. 6a), that between $\sigma_{s p}$ and $>300 \mathrm{~nm}$ particles was 0.93 (Fig. 6b), and that between $\sigma_{s p}$ and $>400 \mathrm{~nm}$ particles was 0.87 . No correlation could be seen between $\sigma_{s p}$ and concentration of $100-200 \mathrm{~nm}$ particles. Probably most of the particles in the accumulation mode are too small to effectively scatter the atmospheric radiation in the visible range. When using the backscattering coefficient instead of scattering coefficient, a behaviour similar to that in Figs. 5 and 6 was observed.

The highest values of $\sigma_{s p}\left(>40 \mathrm{Mm}^{-1}\right)$ were observed

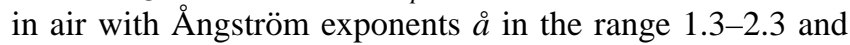
with $\mathrm{SO}_{2}$ concentrations typically smaller than a few $\mu \mathrm{g} / \mathrm{m}^{3}$ (Fig. 7). This indicates that these episodes were dominated by submicron particles from various combustion sources. The largest regional pollution source affecting Northern Finland is the Kola Peninsula industrial area some $350 \mathrm{~km}$ east from Pallas. During periods of air mass transport from this area the highest $\mathrm{SO}_{2}$ concentrations $\left(>10 \mu \mathrm{g} / \mathrm{m}^{3}\right)$ are observed at Pallas (Virkkula et al., 1998; Ruuskanen et al., 2003). Although higher than averages, the values of $\sigma_{s p}$ were mostly below $10 \mathrm{Mm}^{-1}$ in air clearly affected by Kola Peninsula sources. Taken together, these things suggest that the episodes showing the highest values of scattering are associated with long-range transported particulate pollution originating from Central or Eastern Europe rather than by local or regional pollution.

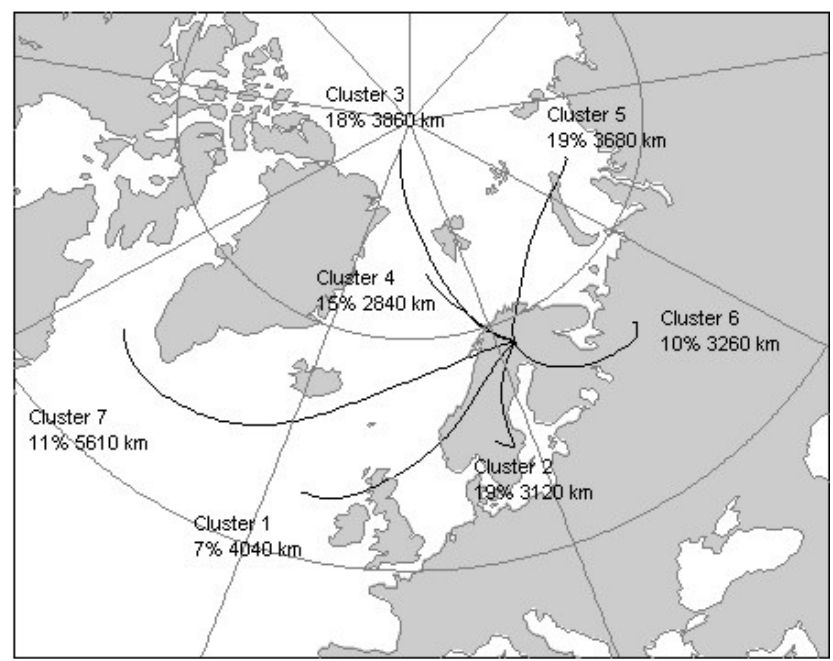

Fig. 8. Transport paths to Pallas illustrated by cluster mean trajectories, denoted 1-7. Percent occurrence of trajectories within each cluster as well as the average trajectory lengths in the different clusters are indicated in the figure.

\subsection{Long-range transport}

Figure 8 shows the calculated climatology for trajectories arriving at Pallas at $925 \mathrm{hPa}$. The clusters are depicted by mean trajectories. The cluster mean represents the average pathway of trajectories in that cluster and describes potential source areas within a 5-day transport time to Pallas. Each cluster is assigned an identification number (1-7). Clusters 3-5 represent transport across the Arctic Basin, clusters 2 and 6 from the Eurasian continent, and clusters 1 and 7 from the Atlantic. The mean trajectory length for each of the clusters is shown in Fig. 8. The highest mean wind speeds, i.e. the longest trajectories, are found in connection with transport over the Atlantic (clusters 1 and 7). Clusters 2, 4 and 6 are associated with the lowest mean wind speeds. Figure 8 also shows the mean frequency of occurrence of the transport clusters. However, this frequency of occurrence co-varies with the seasonal changes of the general circulation patterns (Eneroth et al., 2005).

To study the influence of long-range atmospheric transport on the observed optical aerosol properties at Pallas, the aerosol data were correlated with cluster membership. The data was divided into seven separate groups according to the trajectory climatology. The mean value of the hourly means between $\pm 1 \mathrm{~h}$ of the arrival time of the trajectory was calculated and used in the analysis.

In terms of aerosol properties, the cleanest air conditions were associated with clusters 3 and 7 containing trajectories originating from the Arctic Ocean and the North Atlantic, respectively. These clusters had the lowest average scattering and backscattering coefficients $\left(\sigma_{s p}\right.$ at $550 \mathrm{~nm}$ for clusters 3 and 7 were $3.2 \pm 3.3 \mathrm{Mm}^{-1}$ and $4.0 \pm 3.4 \mathrm{Mm}^{-1}$, respectively) 

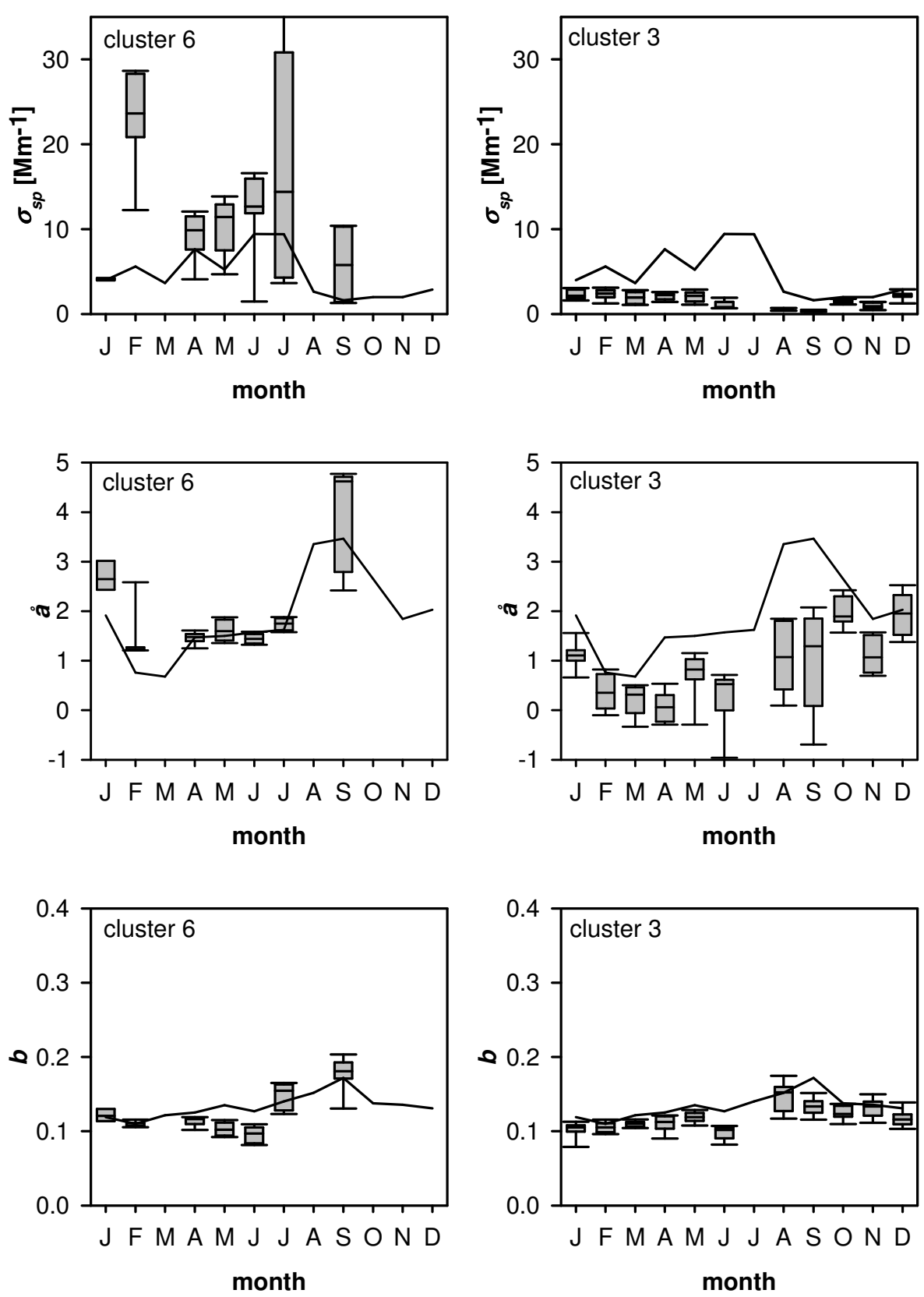

Fig. 9. Box whisker diagrams of the monthly variation of $\sigma_{s p}$ at $550 \mathrm{~nm}$ (top), $a$ (middle) and $b$ at $550 \mathrm{~nm}$ (bottom) for clusters 6 and 3 . The box has a horizontal line at the lower quartile, median and upper quartile values. The whiskers are lines extending from each end of the box to show the 10th and 90th percentiles. The curve shows the median value of all data, regardless of transport pattern.

as well as accumulation mode particle number concentrations for all seasons. The same clusters also showed high nucleation mode particle number concentrations during spring and late summer, which is an indication of new particle formation (Komppula et al., 2003). The most polluted conditions were associated with cluster 1 representing air mass transport from Scandinavia and Britain, and cluster 6, representing air mass transport from Russia and Eastern Europe. Cluster 6 also includes trajectories from the polluted Kola
Peninsula area. Clusters 1 and 6 showed the largest average scattering and backscattering coefficients $\left(\sigma_{s p}\right.$ at $550 \mathrm{~nm}$ were $12.2 \pm 16.8 \mathrm{Mm}^{-1}$ and $16.2 \pm 9.1 \mathrm{Mm}^{-1}$, respectively) as well as the largest accumulation mode particle number concentrations for all seasons. Furthermore, these clusters were associated with year-round low nucleation mode particle number concentrations.

Figure 9 shows monthly variations of $\sigma_{s p}$ at $550 \mathrm{~nm}, \stackrel{\AA}{a}$ as well as $b$ at $550 \mathrm{~nm}$ for clusters 6 and 3, illustrating polluted 
and clean air conditions at Pallas, respectively. From Fig. 9 it can be seen that the Ångström exponent has a clear seasonal pattern for all clusters, with maximum values in autumn and minimum values during winter. The high autumn values of $a$ could possible be related to the maximum cloud frequency observed in Pallas at that time of the year. When clouds are present, the relative amount of large sea-salt and dust particles is likely to be reduced, causing an increase in the value

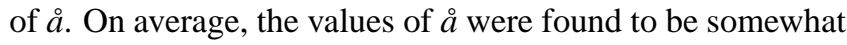
higher in connection with clusters 1,2 and 6 compared to the other transport patterns. This may be due to the dominance of submicron pollution-related particles in these air masses. The highest values of the hemispheric backscattering fraction was observed in autumn for all clusters. No clear linkage between atmospheric circulation and the observed aitken mode and total particle number concentrations was found.

\section{Summary and conclusions}

Three years of continuous measurements of aerosol optical properties have been analysed at Pallas GAW station, a remote subarctic site in the northern border of the boreal forest zone. The measurements were analysed as a function of aerosol size distribution and atmospheric long-range transport. The seasonal variation of the data was also studied. The scattering coefficient at $550 \mathrm{~nm}$ varied from 0.2 to $94.4 \mathrm{Mm}^{-1}$ with an average of $7.1 \pm 8.6 \mathrm{Mm}^{-1}$. Both the scattering and backscattering coefficients had a clear seasonal cycle with an autumn minimum and 4-5 times higher summer maximum. Also the Ångström exponent varied over the year, having a minimum in spring and 2-4 times higher maximum values in late summer. The scattering was dominated by submicron aerosols in Pallas, and especially so during late summer and autumn. The ratio between the backscattering and scattering coefficients was very high at small scattering coefficients. These cases were characterized by very low accumulation mode particle number concentrations, as well as particle size distributions strongly dominated by ultrafine particles.

The scattering coefficient correlated strongly with the number concentration of accumulation mode particles, and even better with the subset of particle larger than about 200$300 \mathrm{~nm}$ in diameter. The relation between $\sigma_{s p}$ and nucleation mode particle number concentration displayed an envelope type pattern, with high values of $\sigma_{s p}$ being associated with low nucleation mode particle number concentration and vice versa. This kind of behaviour is due to the fact that atmospheric new-particle formation at Pallas takes place only in clean air masses originating from the North Atlantic or the Arctic Ocean.

Aerosol data was inspected in terms of trajectory clusters, each of which representing different regions of air masses origin. The cleanest air mass conditions were observed in connection with trajectories coming from the Arctic Ocean and the North Atlantic, showing the lowest average scattering and backscattering coefficients as well as the lowest accumulation mode particle number concentrations all year-round. The most polluted air masses were associated with air mass transport from the Kola Peninsula, Scandinavia and Russia as well as Britain and Eastern Europe. These trajectory clusters had the largest average scattering and backscattering coefficients as well as the largest accumulation mode particle number concentrations for all the seasons.

Our results demonstrate very clearly that the aerosol optical properties, and especially their relation to each other, are strongly dependent on the aerosol number size distribution. In remote locations both particle number concentration and size distribution are highly variable. The main reason for this is the important role of long-range transportation, which is responsible for elevated aerosol concentrations and allows the modification of the aerosol size distribution by secondary aerosol formation, aerosol-cloud interactions and deposition processes. Taken together, these things indicate that understanding the climatic effects of aerosols over remote locations is not possible without the simultaneous measurement of both optical and physical/chemical properties of the aerosols.

Edited by: Y. Rudich

\section{References}

Anderson, T. L., Covert, D. S., Marshall, S. F., Laucks, M. L., Charlson, R. J., Waggoner, A. P., Ogren, J. A., Caldow, R., Holm, R. L., Quant, F. R., Sem, G. J., Wiedensohler, A., Ahlquist, N. A., and Bates, T. S.: Performance characteristics of a high-sensitivity, three-wavelength, total scatter/backscatter nephelometer, J. Atmos. Oceanic Technol., 13, 967-986, 1996.

Anderson, T. L. and Ogren, J. A.: Determining aerosol radiative properties using the TSI 3563 integrating nephelometer, Aerosol Sci. Technol., 29, 57-69, 1998.

Anderson, T. L., Covert, D. S., Wheeler, J. D., Harris, J. M., Perry, K. D., Trost, B. E., Jaffe, D. J., and Ogren, J. A.: Aerosol backscatter fraction and single scattering albedo: Measured values and uncertainties at a coastal station in the Pacific Northwest, J. Geophys. Res., 104, 26 793-26 807, 1999.

Baron, P. A. and Willeke, K.: Aerosol Measurement, 2nd ed., John Wiley, Hoboken, N. J., 2001.

Beine, H. J., Engardt, M., Jaffe, D. A., Hov, Ø., Holmén, K., and Stordal., F.: Measurements of $\mathrm{NO}_{\mathrm{x}}$ and aerosol particles at the Ny-Ålesund Zeppelin mountain station on Svalbard: Influence on regional and local pollution sources, Atmos. Environ., 30, 1067-1079, 1996.

Bodhaine, B. A., Ahlquist, N. C., and Schnell, R. C.: Threewavelength nephelometer suitable for aircraft measurement of background aerosol scattering coefficient, Atmos. Environ., 25A, 2267-2276, 1991

Bodhaine, B.: Aerosol absorption measurements at Barrow, Mauna Loa and the south pole, J. Geophys. Res., 100, 8967-8975, 1995. 
Cabada, J. C., Khlystov, A., Wittig, A. E., Pilinis, C., and Pandis, S. N.: Light scattering by fine particles during the Pittsburgh Air Quality Study: Measurements and modeling, J. Geophys. Res., 109, D16S03, doi:10.1029/2003JD004155, 2004.

Charlson, R. J., Anderson, T. L., and Rodhe, H.: Direct climate forcing by anthropogenic aerosols: quantifying the link between atmosphere sulfate and radiation, Contr. Atmos. Phys., 72, 7994, 1999.

Delene, D. J. and Ogren, J. A.: Variability of aerosol optical properties at four North American surface monitoring sites, J. Atmos. Sci., 59, 1135-1150, 2002.

Eneroth, K., Aalto, T., Hatakka, J., Holmén, K., Laurila, T., and Viisanen, Y.: Atmospheric transport of carbon dioxide to a baseline monitoring station in northern Finland, Tellus, 57B, 366-374, 2005.

Hansen, J., Sato, M., and Ruedy, R.: Radiative forcing and climate response, J. Geophys. Res., 102, 6831-6864, 1997.

Hatakka, J., Aalto, T., Aaltonen, V., Aurela, M., Hakola, H., Komppula, M., Laurila, T., Lihavainen, H., Paatero, J., Salminen, K., and Viisanen, Y.: Overview of the atmospheric research activities and results at Pallas GAW station, Boreal Environ. Res., 8, 365-383, 2003.

Hegg, D. A., Covert, D. S., Rood, M. J., and Hobbs, P. V.: Measurements of aerosol optical properties in marine air, J. Geophys. Res., 101, 12 893-12 903, 1996.

Heintzenberg, J. and Charlson, R. J.: Design and Applications of the Integrating Nephelometer: A Review, J. Atmos. Oceanic Technol., 13, 987, 1996.

Heintzenberg, J., Tuch, T., Wehner, B., Wiedensohler, A., Wex, H., Ansmann, A., Mattis, I., Müller, D., Wendisch, M, Eckhardt, S., and Stohl, A.: Arctic haze over Central Europe, Tellus, 55B, 796-807, 2003.

Intergovernmental Panel on Climate Change: Climate Change 2001: The Scientific Basis (contribution of working group I to the Third Assessment Report of the Intergovernmental Panel on Climate Change), Cambridge Univ. Press, Cambridge, 2001.

Kaufman, Y. J., Tanré, D., and Boucher, O.: A satellite view of aerosols in the climate system, Nature, 419, 215-223, 2002.

Koloutsou-Vakakis, S., Carrico, C. M., Kus, P., Rood, M. J., Li, Z., Shrestha, R., Ogren, J. A., Chow, J. C., and Watson, J. G.: Aerosol properties at a midlatitude Northern Hemisphere continental site, J. Geophys. Res., 106, 3019-3032, 2001.

Komppula, M., Lihavainen, H., Hatakka, J., Paatero, J., Aalto, P., Kulmala, M., and Viisanen, Y.: Observations of new particle formation and size distributions at two different heights and surroundings in subarctic area in northern Finland, J. Geophys. Res., 108, D9, 4295, doi:10.1029/2002JD002939, 2003.

Komppula, M., Lihavainen, H., Kerminen, V.-M., Kulmala, M., and Viisanen, Y.: Measurements of cloud droplet activation of aerosol particles at a clean subarctic background site, J. Geophys. Res., 110, D06204, doi:10.1029/2004JD005200, 2005.
Lohmann, U. and Feichter, J.: Global indirect aerosol effects: a review, Atmos. Chem. Phys., 5, 715-737, 2005.

O'Dowd, C. D. and Smith, M. H.: Physico-chemical properties of aerosols over the Northeast Atlantic: Evidence for wind-speedrelated sub-micron sea-salt aerosol production, J. Geophys. Res., 98, 1137-1149, 1993.

Ramanathan, V., Crutzen, P. J., Kiehl, J. T., and Rosenfeld, D.: Aerosols, climate, and the hydrological cycle, Science, 294, 2119-2124, 2001.

Romesburg, H. C.: Cluster analysis for Researchers, Lifetime Learning Publications, Belmont, California, 1984.

Ruuskanen, T. M., Reissell, A., Keronen, P., Aalto, P. P., Laakso, L., Grönholm, T., Hari, P., and Kulmala, M.: Atmospheric trace gas and aerosol particle concentration measurements in Eastern Lapland, Finland 1992-2001, Boreal Environ. Res., 8, 335-349, 2003.

Seinfeld, J. H. and Pandis, S. N.: Atmospheric chemistry and physics. From air pollution to climate change, John Wiley \& Sons, Inc., New York, 1998.

Sheridan, P. J. and Ogren, J. A.: Observations of the vertical and regional variability of aerosol optical properties over central and eastern North America, J. Geophys. Res., 104, 16793-16 805, 1999.

Stohl, A. and Koffi, N. E.: Evaluation of trajectories calculated from ECMWF data against constant volume balloon flights during ETEX, Atmos. Environ., 24, 4151-4156, 1998.

Stohl, A. and Wotawa, G.: A method for computing single trajectories representing boundary layer transport, Atmos. Environ., 29, 3235-3239, 1995.

Stohl., A., Haimberger, L., Scheele, M. P., and Wernli, H.: An intercomparison of results from three trajectory models, Meteorol. Appl., 8, 127-135, 1999.

Treffeisen, R., Herber, A., Ström, J., Shiobara, M., Yamanouchi, T., Yamagata, S., Holmén, K., Kriews, M., and Schrems, O.: Interpretation of Arctic aerosol properties using cluster analysis applied to observations in the Svalbard area, Tellus, 56B, 457476, 2004.

Virkkula, A., Hillamo, R. E., Kerminen, V.-M., and Stohl, A.: The influence of Kola Peninsula, continental European and marine sources on the number concentrations and scattering coefficients of the atmospheric aerosol in Finnish Lapland, Boreal Environ. Res., 2, 317-336, 1998.

Vrekoussis, M., Liakakou, E., Kocak, M., Kubilay, N., Oikonomou, K., Sciare, J., and Mihalopoulos, N.: Seasonal variability of optical properties of aerosols in the Eastern Mediterranean, Atmos. Environ., 39, 7083-7094, 2005. 